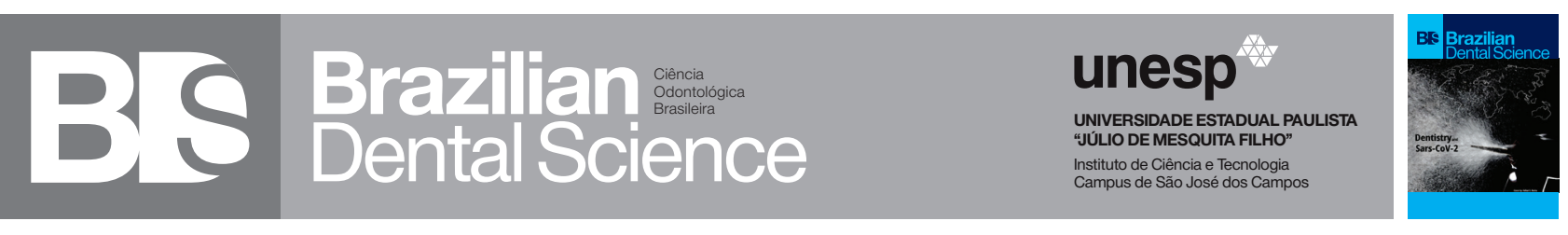

\title{
Hospital Dentistry and Dental Care for Patients with Special Needs: Dental approach during COVID-19 Pandemic
}

\author{
Odontologia Hospitalar e Assistência Odontológica para Pacientes com Necessidades Especiais: Abordagem \\ odontológica durante a Pandemia de COVID-19

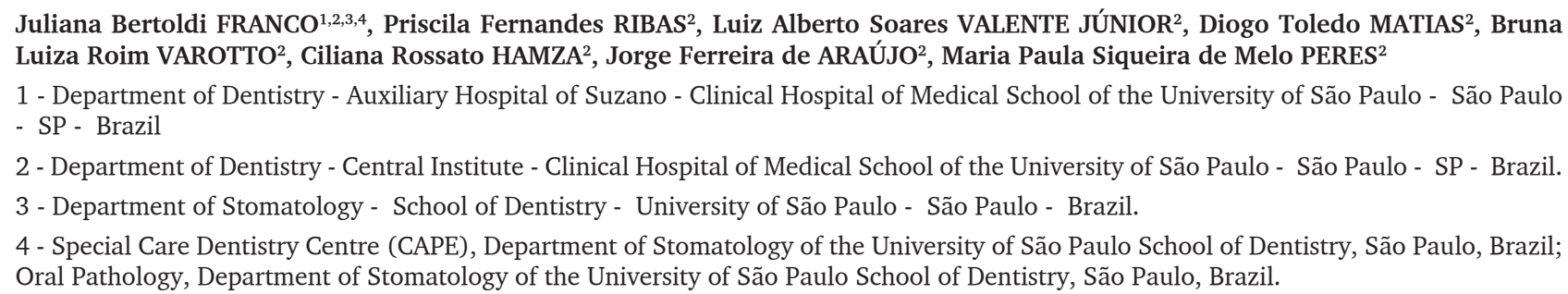

\section{ABSTRACT}

Introduction: The COVID19 pandemic brought a new panorama for the realization of dental treatment for the general population due to the risk of cross infection in the dental office, aerosol formation and insertion of new personal protective equipment. Emergency and emergency dental criteria were defined to limit the flow of patients in the office in order to improve biosafety conditions among patients. Objective: to describe the dental procedures pertinent to outpatient special care or during hospitalization in the COVID19 pandemic, changes in care and implement biosecurity criteria. Basic procedures: The dental care of the special patient suffers changes, mainly referring to the difficulty of access to the offices, interruption of the conditioning process and difficulty to perform outpatient sedation and sedation with nitrous oxide. Dental care during hospitalization is essential in this patient due to prolonged time of tracheal oro intubation, traumatic oral lesions, preparation of specific oral care protocols, removal of mouth infectious and installation of mouth protectors. Conclusion: Change of care, inclusion of individual protection equipment and new knowledge about the COVID19 allows us to safely assist the patient with special needs both in the dental office and in hospital environment, providing quality of life, oral comfort and reducing oral infections during and after the pandemic.

\section{KEYWORDS}

Dental care; Hospitals, Special; Needs assessment; Dental service, Hospital; Intensive Care Units; Pandemics.

\section{RESUIMO}

Introdução: A pandemia por COVID19 trouxe um novo panorama para a realização do tratamento odontológico para a população em geral devido ao risco de infecção cruzada no consultório odontológico, formação de aerossóis e inserção de novos equipamentos de proteção individual. Critérios de emergência e urgência odontológicos foram definidos para limitar o fluxo de pacientes no consultório com o objetivo de melhoras as condições de biossegurança entre os pacientes. Objetivo: Citar os procedimentos odontológicos pertinentes ao atendimento de paciente com necessidades especiais em âmbito ambulatorial ou hospitalar durante a pandemia por COVID19, alterações nos fluxos de atendimentos e cuidados inerentes a assistência. Procedimentos básicos: $\mathrm{O}$ atendimento odontológico do paciente com necessidades especiais sofreu alterações, principalmente referente a dificuldade de acesso aos consultórios, interrupção do processo de condicionamento e dificuldade para a realização de sedação ambulatorial e sedação com óxido nitroso. A assistência odontológica durante a hospitalização por COVID19 é fundamental devido ao tempo prolongado de intubação oro traqueal - lesões orais traumáticas, elaboração de protocolos de cuidados bucais específicos, remoção de focos infecciosos bucais e instalação de protetores bucais. Conclusão: Mudanças nas rotinas de atendimento, inclusão de equipamentos de proteção individual e de novos conhecimentos sobre a COVID19 faz com que possamos atender com segurança o paciente com necessidades especiais tanto no consultório odontológico quando em ambiente hospitalar, proporcionando qualidade de vida, conforto oral e redução das infecções bucais durante e após a pandemia.

\section{PALAVRAS-CHAVE}

Assistência odontológica; Hospitais especializados; Determinação de necessidades de cuidados de saúde; Unidade hospitalar de odontologia; Unidades de Terapia Intensiva; Pandemias. 


\section{INTRODUCTION}

$\mathrm{T}$ he COVID-19 pandemic brought great changes to dentistry due to the high possibility of transmission of the SARS-CoV-2 virus by aerosols formed during the dental procedures or through contaminated areas in the dental office [1-4].

Issues about the adequacy of dental and biosafety procedures are opportune and generate major questions by professionals in the area, as well as possible changes for the future [1].

Dental care for patients with special needs has become a major challenge at this time. Besides being considered a risk group for COVID-19, these patients require a high number of consultations for conditioning and creating a good relationship with the professional, and most of the times, they need oral or inhaled drug sedation for many procedures $[5,6]$.

Hospital dentistry is seen as a new area of dentistry performance, even though it has been present in hospitals for a long time. It has always been a great ally for the improvement of oral health in hospitalized patients or in systemically complex patients who need hospital backup to perform dental procedures. The COVID-19 pandemic has shown that dentists who work in hospitals are more used to biosafety, due to the routine care of patients with respiratory infections or other infectious diseases [1, 5-7].

Thus, the understanding of the needs of this group of patients in relation to dental procedures to be performed, time and place of care, associated with concepts of biosafety must always be remembered in this moment of pandemic, to carry out a safe dental treatment.

\section{CLINICAL PROTOCOLS}

\section{Dentistry for Patients with Special Needs and Hospital Dentistry: Concept.}

In the last decades, the world has presented an important change in the context regarding the characteristics of its population, with a lower birth rate and a longer life expectancy, which leads to the acquisition of important pathologies, related to living longer, but also related to early diagnosis of many diseases, creating a specific, more specialized, multidisciplinary dental demand with the execution of specific care protocols $[5,8]$.

Thus, patients with special needs are those who have disabilities (physical, mental, sensory, developmental, behavioral, emotional, cognitive and movement deficits) and congenital or acquired systemic pathologies (systemic health problems that require programs or specialized treatment services) $[5,6,9,10]$.

In recent past, care for patients with special needs used to be the responsibility of pediatric dentistry, resulting from the care of syndromic or neurological patients who require conditioning for dental treatment. In 2001, during the II National Assembly of Dental Specialties (ANEO), Dentistry for Patients with Special Needs was created as a dental specialty responsible for assisting neurological, syndromic, autistic and systemically complex patients [5].

Classically, Oral and Maxillofacial Surgery and Traumatology has always been the dental specialty present in hospitals for treatment of facial trauma, deformities and resection of odontogenic tumors. Nevertheless, dentists of any specialty can also attend patients using resources of an operating room, under general anesthesia or sedation [7].

Hospital dentistry is characterized by the care of patients who need backup in a hospital environment due to specific situations for dental procedures to be performed. The service can be performed in an outpatient clinic (dental office inside the hospital), or during the patient's hospitalization, taking place in the wards, in the Intensive Care Unit (ICU), emergency room, operating room and at home. Thus, the dental surgeon will attend hospitalized patients either due to the worsening of the underlying condition or because of dental issues [7].

Working in a hospital environment requires some skills that are not part of the dental routine, such as integration and working with the interdisciplinary team. This knowledge is acquired on a daily basis through this joint 
teamwork that aims to provide care by several professionals, who communicate with each other and carry out procedures to widely assist the patient. Thus, there is also a need for the presence of a clinical dentist to perform routine dental procedures during hospitalization of patients undergoing treatment due to general health condition, not only in cases of facial trauma or major oral surgery $[5,7,11,12]$.

Due to the need for specific knowledge to work in hospitals, the Federal Council of Dentistry of Brazil (CFO) created in 2015 the Qualification in Hospital Dentistry, which certifies that the professional is qualified to perform procedures in this specific environment [13].

The bedside dental treatment is a form of care provided in a hospital environment (figure 1), performed when the patient is admitted to the ward, ICU, operating room or at home, presenting mobility restrictions (whether physical or due to severe disease) or due to the lack of a dental office within the hospital. It is an unconventional form of care, but it brings accessibility of dental treatment to the patient regardless of the place of hospitalization [7].

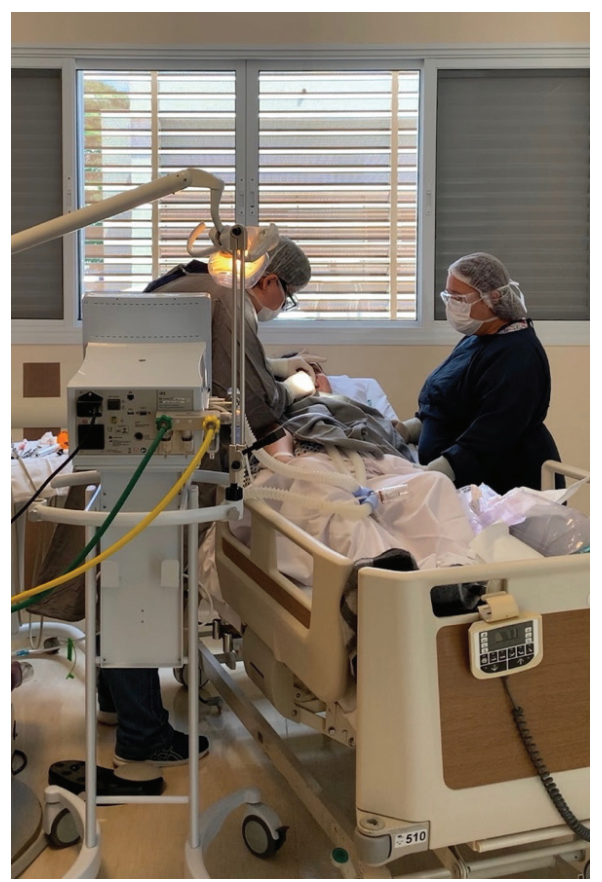

Figure 1- Dental care at the bedside in a patient on mechanical ventilation.

\section{SARS-CoV-2 / COVID19 / Saliva transmission / Droplets and aerosols}

The acute respiratory disease caused by SARS-CoV-2 ("Severe Acute Respiratory Syndrome Coronavirus 2"), a virus of unknown characteristics, was firstly detected in Wuhan, Hubei, China, with the increase in the number of pneumonia cases of unknown etiology, followed by spread and expressive growth in the number of cases in other regions and countries of the world $[14,15]$.

The current outbreak of the Coronavirus 2019-nCoV strain (COVID-19) constitutes a public health emergency of global concern, due to its high virulence and power of dissemination in the population, which causes a high demand for highly complex hospital care due to respiratory failure and other systemic compromises $[14,15]$.

So far, the clinical course of the disease is heterogeneous, with a portion of patients presenting an asymptomatic clinical course while another portion evolving with a mild/ moderate or severe manifestation, according to the severity of the underlying condition [16].

The SARS-CoV-2 virus has a tropism for cells that have the cell receptor ACE2 (angiotensin-converting enzyme 2), and the cell once infected will be used for viral replication. The ACE2 receptor can be found in the oral mucosa, tongue, gums, salivary glands, taste buds and respiratory mucosa, which causes the detection of the virus in saliva - oral cavity and nasal cavity [17-19].

Hence, there are four hypotheses for SARS-CoV-2 to be present in saliva: 1 ) the virus present in the lower and upper respiratory tract comes into direct contact with the oral cavity, contaminating this region; 2) the virus in the blood can access the oral cavity via gingival crevicular fluid, through the specific exudate that contains local proteins present in the extracellular matrix and proteins derived from serum; 3) SARS-CoV-2 may be present in the oral cavity because of the infection of 
the minor and major salivary glands, with subsequent release of viral particles in the saliva via salivary ducts; 4) presence of the ACE2 cell receptor in the oral mucosa and salivary glands $[4,18]$.

A study showed that SARS-CoV-2 has viable virus titer in a period of up to 3 hours for aerosols, with an estimated average of 1.1 hours, in a controlled environment, with a half-life for the virus on surfaces such as plastic and steel of 6.8 hours and 5.6 hours, respectively [3].

The COVID-19 pandemic is a reminder that dental surgeons should be concerned with the spread of infectious respiratory diseases, especially regarding the formation of aerosols during dental care, and strategies to avoid them must be adopted during the pandemic [1].

Urgent and Emergency Dental Procedures in Patients with Special Needs and Hospital Dentistry at a time of COVID-19 Pandemic.

During COVID-19 pandemic only dental urgencies and emergencies should be performed, in order to reduce the formation of aerosols from the procedures and restrict the flow of patients to the offices. Moreover, the indiscriminate performance of dental procedures during the pandemic can be considered more as a harm to the population than a proper aid [1].

Dental emergency procedures are defined as those performed for hemostasis of oral bleeds; drainage of cellulite or dental abscesses; major oral surgery in trauma involving the facial bones, with potential involvement of the patient's airway $[1,20]$.

Urgent dental care includes those procedures for resolving pain of dental or soft tissue origin; infection of odontogenic origin; oral bleeding; and oral necrosis (figure 2) $[1,20]$.

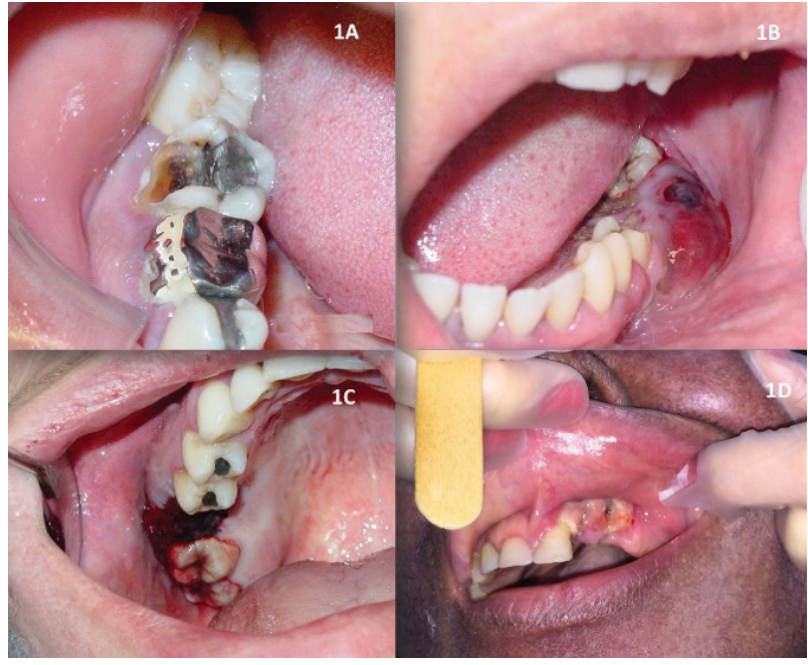

Figure 2 - Examples of dental urgencies. 2A- Tooth with great coronary destruction associated with pain; 2B- Dental abscess (infection); 2C- Oral bleeding; 2D- Oral necrosis.

Other procedures that should be added are related to cancer patients and systemically complex patients, such as treatment of oral mucositis with an indication for treatment with laser therapy; dental treatment based on the removal of oral foci prior to a critical medical procedure; biopsy of abnormal oral tissue changes (potentially malignant disorders) $[1,20]$.

Besides, other exclusive procedures to be performed in a hospital environment (in wards and ICU) should be included, such as installation of EVA mouthguards (ethylenevinyl acetate) in patients intubated in the ICU with trauma to the soft tissues and orotracheal tube; treatment of traumatic injuries in patients intubated in the ICU; relining of complete prosthesis for progression of oral diet [21].

Dentistry for Patients with Special Needs and Hospital Dentistry in times of COVID-19 pandemic.

Patients with special needs, including patients with systemic pathologies, as they are considered a risk group during the COVID-19 pandemic, some care must be taken to ensure that dental care occurs safely [1].

Due to the restriction of dental care for urgent and emergency procedures during 
the COVID-19 pandemic, patients with special needs in outpatient or hospital care will discontinue both the treatment and conditioning. Ideally, these patients and family members are advised by phone to contact the dental service, professionals or hospital staff in case of pain, infection, bleeding or any other change in the oral cavity $[1,20]$.

For patients with cognitive impairment or those who cannot speak, the family/caregiver should pay attention if the patient presents a painful face during the day or the meal, or if he/she stops eating due to dental pain, as well as drooling or swelling in the face. Dental pain, changes in behavior (patient touching the face or head) and any changes must be reported to the patient's dentist $[6,9]$.

We emphasize that ambulatory sedation and/or the use of nitrous oxide is not indicated at this time, due to the restriction of access to hospital services, in case of any complications during the procedure. The use of physical or mechanical restraint can be used, remembering that it must be explained to the patient's legal guardian about the procedure, advantages, disadvantages and a free and informed consent form must be signed prior to the procedure [22]. The use of patient restraints or stabilizing mattresses can be used at this time but must be cleaned and disinfected after care [1].

At this moment there are restrictions for dental care under general anesthesia due to the lack of hospital beds that are being used to care for the patient with COVID19, and the risk of contamination during hospitalization to perform general anesthesia. But in some cases, we should consider the performance of general anesthesia as: patients who have had trauma to the permanent dentition which needs intervention or patients who have acute dental infection that is not responsive to antibiotics or patients who have facial swelling as a result of dental decay and treatment under local anaesthetic or sedation is not possible; patients with additional needs such as those with learning disability or autism, where dental pain is resulting in self harm or patients who have a compromised swallow and are at risk of aspirating a tooth which cannot be removed and treatment is not possible under local anaesthetic $[1,5,6]$.

It is important to highlight that many medical treatments cause a worsening of the patients' oral healt, as well as oral infection foci influence the underlying pathology, worsening the patient's systemic condition [1].

We advise that since they are patients in the risk group, without signs and symptoms of COVID-19, they should be seen in the first hours of the office's operation, as this results in access to a less contaminated environment and a smaller flow of people.

\section{Outpatient Dental Care}

Outpatient dental care can occur both in the conventional dental office and inside the hospital, if there is a room with a dental chair.

Because the SARS-CoV-2 virus is transmitted through the respiratory tract and by contact, procedures that do not generate aerosols are the best prevention for the spreading of the virus in the dental environment. Thereby, for urgent and emergency dental procedures, the professional should adopt the use of manual instruments, use of irrigation with a manual syringe with saline solution instead of the triple syringe, the use of drying the cavity preparation with cotton instead of air spray and continuous aspiration are recommended for this moment $[1,20]$.

The use of the spittoon, a potential aerosol-forming instrument, as well as the high-speed handpiece and the ultrasonic scalers, must be avoided at this time [1]

The care inherent in the waiting room, bathrooms, dental office must be adopted for each patient, remembering the complete use of PPE for all patients and procedures to be performed [1].

As the patient with special needs requires someone together with them in the vast majority of cases, the guidelines regarding the use of a mask, appearing just at the scheduled appointment time, social distance, respiratory etiquette and avoidance of shake hands should be reinforced $[1,2,14,15]$. 
Bearing in mind that according to the time for the aerosol sedimentation, the patient's appointment must respect this waiting and disinfection period, abruptly changing the appointment for patients $[1,3]$.

It should be emphasized that the dental care to the positive COVID19 patient should be performed only in cases of dental emergency, and the patient should be scheduled for the last office hours, reducing the exposure of other patients to aerosols and providing the terminal cleaning of the office after this care.

\section{Hospital Dental Care}

In a time of COVID-19 pandemic, the exclusive hospital assistance is the bedside dental care, either for patients admitted to the ward or in the ICU. This includes all patients who are hospitalized due to a general medical condition, and who present any dental complaint expressed by the patient himself or by someone from the multiprofessional team that assists him. Active patient search routines regarding oral condition can be performed as long as PPE is available for this assessment $[1,7]$.

This service decreases the formation of aerosols but requires the use of complete PPE, skill and experience for the safe performance of dental care $[1,7]$.

The dental procedures performed in the wards and ICUs will depend on the professional's skill, available infrastructure and the general health condition of the patient.

Indications for dental treatment are those based on dental urgencies and emergencies, associated with recommendations relevant to the hospital environment.

Dental care for this group of patients generated a very specific demand, mainly related to dental trauma during difficult orotracheal intubation, which leads to the indication of tooth extraction, as well as for patients with advanced periodontal disease presenting great dental mobility and risk of bronchoaspiration of the teeth during intubation and orotracheal extubation [1].

Also, we emphasize that patients with COVID-19 can progress to respiratory failure requiring orotracheal intubation and mechanical ventilation for long periods, which causes ulcerated lesions on the lip and oral mucosa, trauma related to the tube with decreasing of saturation, requiring the installation of mouthguards and treatment of soft tissue injuries (laser therapy, hydration and corticosteroids) (figure $3 \mathrm{~A}$ e $3 \mathrm{~B}$ ) $[1,21]$.

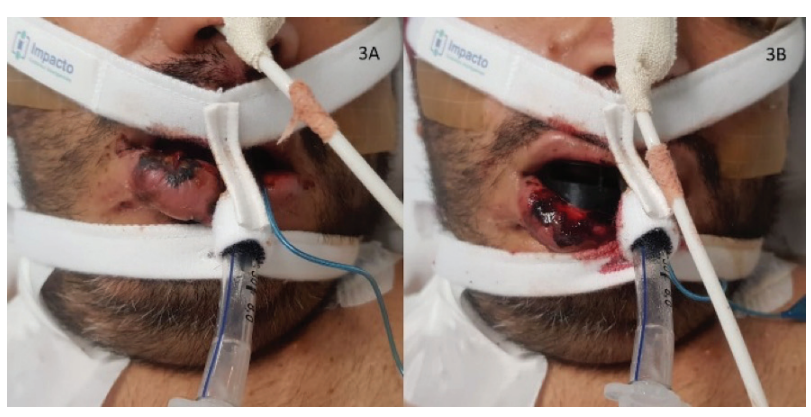

Figure 3 - 3A- Patient on mechanical ventilation diagnosed with COVID-19 presenting trauma related to the orotracheal tube and in the lower lip. 3B- Installation of EVA mouthguard.

Since these patients are in the ICU, which represents a lack of mobility - and anticoagulation has been one of the treatments for COVID-19, bloody dental procedures present a risk of bleeding - in addition to the risk of spontaneous gingival and oral mucosa bleeding. In these cases, the use of local hemostatic measures is essential to contain bleeding either spontaneous or resulting from traumatic oral injury, and to perform the tooth extractions. It is recommended as a hemostatic agent: cellulose sponge, macerated tranexamic acid mixed with saline and oxidized cellulose $[23,24]$.

A condition frequently found in the ICU are cases of drooling in which the patient has a leak of saliva through the mouth and/ or nose (figure 4), or the accumulation of secretion in the oral cavity, providing a risk of bronchoaspiration and difficulty in extubation. In these cases, drying methods should be employed, such as the use of sublingual atropine, sublingual tropicamide, scopolamine (orally, via nasogastric tube, via gastrostomy or transdermal), and application of botulinum toxin to the salivary glands. The 
use of drying methods reduces salivary flow and improves the drooling condition. The use of medications is a reversible treatment, which means that the reduction in salivary flow occurs only during the effect of the drug, unlike botulinum toxin that has a lasting effect varying from 4 to 6 months [11].

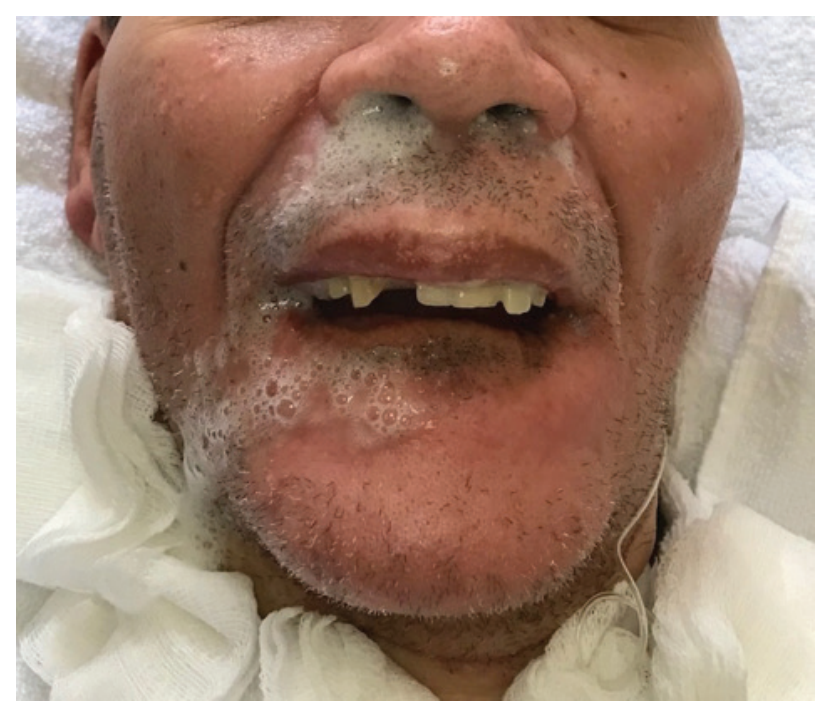

Figure 4 - Patient presenting drooling with saliva escaping through the nasal and oral cavity.

Besides dental procedures, we call attention to multidisciplinary teamwork in conducting training for oral care protocols in an ICU patient, such as oral hygiene, aspiration and lip hydration. We guide the continuity of oral hygiene protocols using $0.12 \%$ chlorhexidine for chemical-mechanical control of dental biofilm, providing gingival health, control of oral microbiota and reduction of ventilatorassociated pneumonia (VAP), a respiratory infection of bacterial origin [7].

\section{Home Dental Care}

Some patients with special needs have reduced mobility that hinders access to the dental office. Home care can be performed as long as the professional follows the concepts of biosafety, especially considering that the professional must not be infected with SARS-CoV-2 since it could contaminate the patient and family with the visit to perform the procedure. Therefore, the use of N95 mask and full PPE reduces this possibility of transmission, as well as the performance of dental procedures that contemplate exclusively dental urgencies and emergencies at this time [25].

\section{Biosafety}

It is important to note that currently all patients should be considered as potentially contaminated by SARS-CoV-2 virus, and all concepts of biosafety should be applied to all consultations.

Franco, Camargo and Peres, in 2020, highlighted the importance of PPE for dental treatment during the COVID-19 pandemic, mainly the use of the N95 respirator, due to the aerosol generation by dental procedures, especially when using handpiece and triple syringe. When affordable, the professional should adopt the use of manual instruments, low-speed handpiece, use of a rubber dam, irrigation with a syringe with saline (figure 5), in order to avoid the formation of these aerosols [1].

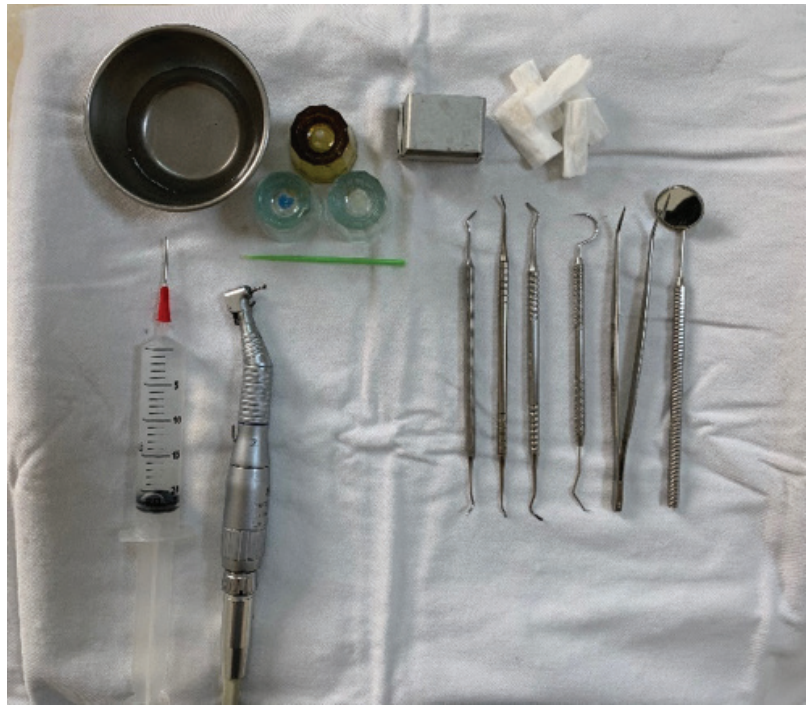

Figure 5 - Use of manual instruments - low-speed handpiece and syringe with saline to reduce the formation of aerosols.

The PPE to be used in all dental care are: respirator N95 / PFF2, goggles, disposable head cover, face shield, waterproof and 
disposable surgical gown, surgical pyjamas, shoe cover. Moreover, training is required for the sequence of vestments and the separation of PPE (figure 6). The equipment must be used by all professionals, assistants and cleaning staff $[1,26,27]$.
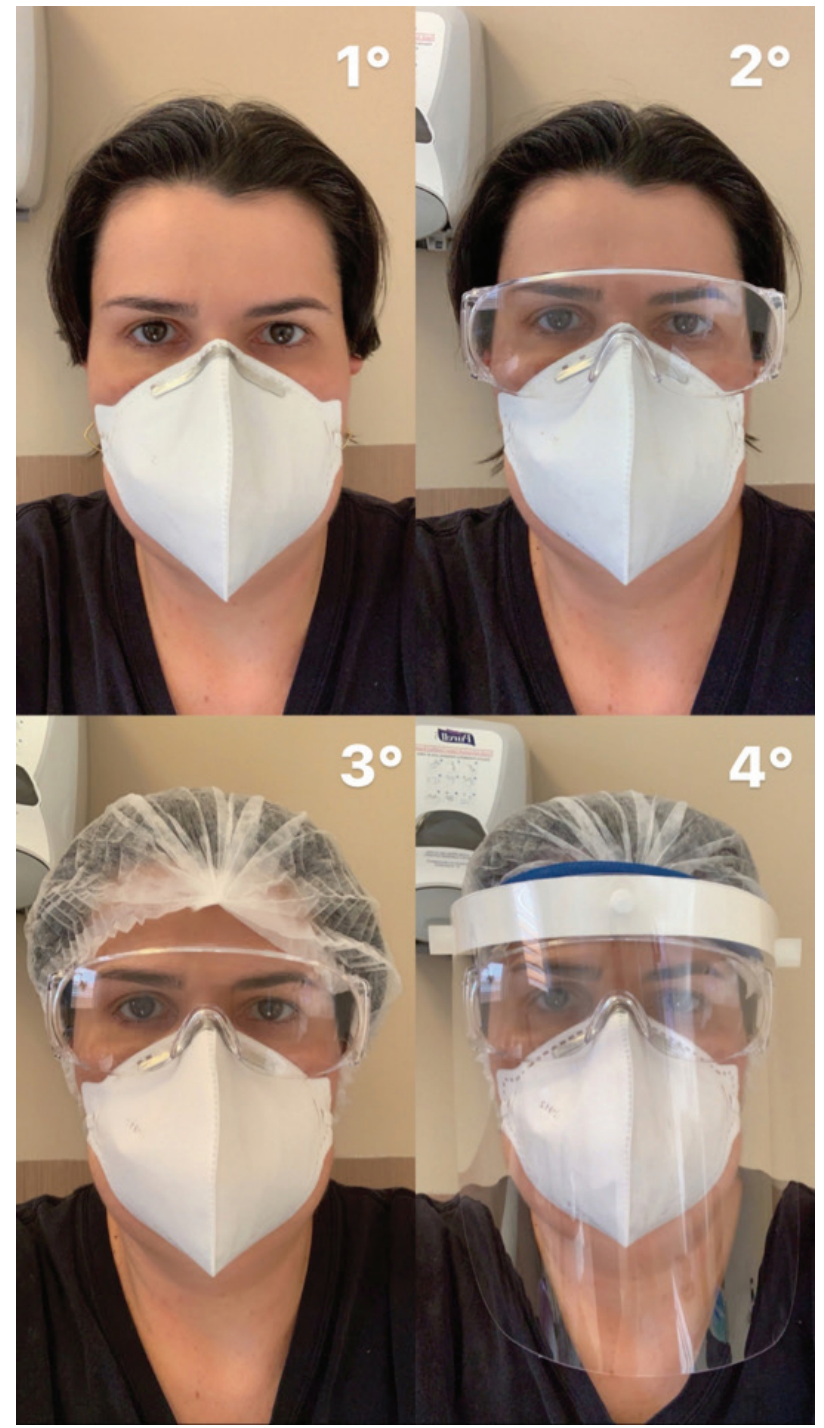

Figure 6 - Sequence of PPE dressing: 1st - placement of the N95 mask; 2nd - putting on protective goggles; 3rd - wearing head cover; 4th - placement of the face shield. Removing the equipment must follow the reverse order.

After the whole procedure ends, it is mandatory to wait an enough time for the aerosol sedimentation to begin the process of disinfecting the surface of the dental chair and furniture. This period is quite variable and depends on the availability of air circulation in the office after the procedure, varying among procedures, and also according to the presence of windows or not for air circulation in the office $[1,3,28]$.

The cleaning and disinfection procedure of the dental office must be carried out with the cleaning of dirt and organic matter, and then disinfection can be carried out with 70INPM or $77 \mathrm{GL}$ alcohol. The use of $50 \%$ quaternary ammonia promotes cleaning and disinfection of surfaces in a single step [1,2, 28-30].

Another crucial point is that the use of PPE by professionals might difficult their identification by the patients, mainly those with special neurological or syndromic conditions. Strategies of conditioning such as making videos showing the dressing process to show to them by the parents or legal guardians in order to the patient being able to see their dentist getting dressed [6].

\section{FINAL CONSIDERATIONS}

The COVID-19 pandemic generated a major change in dental care routines, mainly due to the possibility of transmission of the SARS-CoV-2 virus by aerosols. At this time, common sense regarding performing dental procedures limited to urgent and emergency cases is important to restrict contamination of the dental office environment. Elective procedures can be performed mainly when referring to patients with special needs or systemic impairment, who must continue medical treatment, with dental treatment being essential for the removal of foci of infection.

Hospital dentistry enriches and brings many routines for dental care to patients with respiratory infections, concerning to biosafety care that should be used routinely in the dental office.

The use of PPE must be implemented for dental care at this time, with the insertion of N95 respirators, warnings inherent to the patient, to follow-up, dental office and special care for disinfecting the dental chair, peripherals and furniture. 
Oral health is essential for maintaining general health, thus dental care is fundamental for all patients and should be implemented by well trained professionals, regardless of where the patient is, aiming to assist in clinical improvement and quality of life.

\section{REFERENCES}

1. Franco JB, Camargo AR, Peres MPSM. Cuidados Odontológicos na era do COVID-19: recomendações para procedimentos odontológicos e profissionais Rev Assoc Paul Cir Dent.2020;74(1):18-21.

2. Peng $X, X u X, L i Y$, Cheng L, Zhou X, Ren B. Transmission routes of 2019-nCoV and controls in dental practice. Int J Oral Sci. 2020;12(1):9. doi:10:1038/s41368020-0075-9

3. van Doremalen N, Bushmaker T, Morris DH, Holbrook MG, Gamble A, Williamson BN, etal. Aerosol and Surface Stability of SARS-CoV-2 as Compared with SARS-CoV-1. NEngl J Med. 2020;382(16):1564-7. doi:10.1056/ NEJMc2004973

4. Sabino-Silva R, Jardim ACG, Siqueira WL. Coronavirus COVID-19 impacts to dentistry and potential salivary diagnosis. Clin Oral Investig. 2020;24(4):1619-21. doi:101007/s00784-020-03248-X

5. Franco JB, Ortega KL, Medina JB. Pacientes portadores de doenças neurológicas. Manual de Especialização - Odontologia Hospitalar (Einstein). São Paulo:Manole; 2019.

6. Polli VA, Sordi MB, Lisboa ML, MunhozEA, Camargo AR. Dental management of special needs patients: a literature review. Global J Oral Sci. 2016;2:33-45.

7. Franco JB, Jales SMCP,Zambon CE, Fujarra FJC, Ortegosa MV, Guardieiro PFR, et al. Higiene bucal para pacientes entubados sob ventilação mecânica assistida na unidade de terapia intensiva: proposta de protocolo. Arq Med Hosp Fac Cienc Med Santa Casa São Paulo. 2014;59:126-31.

8. Meurman JH, McKenna G, Murtomaa H, Nakao M,Ogawa H, Walls A, et al. Managing our older population: the challenges ahead. J Dent Res. 2018:97(10):1077-8. doi:10.1177/0022034518784916

9. Queen AN. Evidence-based dentistry and its role in caring for special needs patients. Dent Clin North Am. 2016;60(3):605-11. doi:101016/j.cden.2016.02.002

10. Glassman P,Subar P.Planning dental treatment for people with special needs. Dent Clin North Am. 2009;53(2):195-viii. doi:10.1016/j.cden.2008.12.010

11. Franco JB, Cacita N, Freua KA, Ortega KL, de Melo Peres MPS. Treatment of drooling with scopolamine in pediatric ICU: a case series report. Spec Care Dentist. 2018;38(6):362-6. doi:10.1111/scd.12326

12. Bassan LT, Peres MPSM, Franco JB. Oral care in prevention of ventilatorassociated pneumonia in neonatal and pediatric intensive care unit: protocol proposal. Rev Bras Odontol. 2018;75:1-7.

13. Conselho Federal de Odontologia (CFO). Resolução CFO N-162 de 3 de Novembro de 2015. Reconhece o exercício da Odontologia Hospitalar pelo cirurgião-dentista. Brasilia:Diário Oficial da União;2015 nov 16.

14. Huang C, Wang Y,Li X, Ren L, Zhao J, Hu Y, etal. Clinical features of patients infected with 2019 novel coronavirus in Wuhan, China. Lancet. 2020;395(10223):497-506. doi:10.1016/S0140-6736(20)30183-5
15. Zhu N, Zhang D, Wang W, LiX, Yang B, Song J, et al. A novel coronavirus from patients with pneumonia in China, 2019. N Engl J Med. 2020;382(8):727-33. doi:101056/NEJMoa2001017

16. Bai Y, Yao L, Wei T, Tian F, Jin DY, Chen L, et al. Presumed asymptomatic carrier transmission of COVID-19. JAMA. 2020;323(14):1406-7. doi:101001/ jama.2020.2565

17. To KK, Tsang OT, Leung WS, Tam AR, Wu TC, Lung DC, etal. Temporal profiles of viral load in posterior oropharyngeal saliva samples and serum antibody responses during infection by SARS-CoV-2: an observational cohort study. Lancet InfectDis.2020:20(5):565-74 doi:101016/S1473-3099(20)30196-1

18. Xu H,Zhong L, Deng J, Peng J, Dan H, Zeng X, et al. High expression of ACE2 receptor of 2019-nCoV on the epithelial cells of oral mucosa. Int J Oral Sci. 2020;12(1):8. doi:10.1038/s41368-020-0074-x

19. To KK, Tsang OT, Chik-Yan Yip C, Chan KH, Wu TC, Chan JMC, et al. Consistent detection of 2019 novel coronavirus in saliva. Clin Infect Dis. 2020;ciaa149. doi:101093/cid/ciaa149

20. American Dental Association. Covid-19Resources for dentists [Internet]. [cited 2020 Apr 28]. Available from: www.ada.org/en/member-center/coronavirusresource-toolkitfor-ada members.

21. Franco JB, Barquette NM, Jales SMCP, Zambon CE, Guardieiro PFR, Matias DT, etal. Utilização de protetores bucais em pacientes internados na unidade de terapia intensiva: proposta de protocolo. Arq Med Hosp Fac Cienc Med Santa Casa São Paul0. 2015;60:85-90

22. Souza RCC, Costa OS, Costa LR. Dental sedation precautions and recommendations during the COVID-19 Pandemic. Rev Bras Odontol. 2020;77:e1788.

23. Coulthard P.Dentistry and coronavirus (COVID-19) - moral decision-making. $\mathrm{B}$ Dent J. 2020;228(7):503-5. doi:10.1038/s41415-020-1482-1

24. Wahl MJ. The mythology of anticoagulation therapy interruption for denta surgery. J Am Dent Assoc. 2018;149(1):e1-e10. doi:10.1016/j.adaj.2017.09.054

25. British Society for Disability and Oral Health Working Group. The development of standards for domiciliary dental care services: guidelines and recommendations. Gerodontology.2000;17(2):119-22. doi:10.1111/j.17412358.2000.00119x

26. Long Y,Hu T,Liu L, Chen R, Guo Q, Yang L, et al. Effectiveness of N95 respirators versus surgical masks against influenza: a systematic review and metaanalysis. J Evid Based Med. 2020;13(2):93-101. doi:10.1111/jebm.12381

27. Wang $X$, Pan Z, Cheng Z. Association between 2019-nCoV transmission and N95 respirator use. JHosp Infect. 2020;105(1):104-5. doi:10.1016/j. jhin.2020.02.021

28. Frauenfelder C, Butler C, Hartley B, Cochrane L, Jephson C, Nash R, etal. Practical insights for paediatric otolaryngology surgical cases and performing microlaryngobronchoscopy during the COVID-19 pandemic. Int J Pediatr Otorhinolaryngol. 2020;134:110030. doi:10.1016/j.jporl.2020.110030

29. Kampf G, TodtD,Pfaender S, SteinmannE. Persistence of coronaviruses on inanimate surfaces and their inactivation with biocidal agents. J Hosp Infect 2020;104(3):246-51. doi:10.1016/j.jhin.2020.01.022

30. Eggers M, Eickmann M,Zorn J. Rapid and effective virucidal activity of povidone-iodine products against middle east respiratory syndrome coronavirus (mers-cov) and modified vaccinia virus ankara(MVA). Infect Dis Ther. 2015;4(4):491-501. doi:10.1007/s40121-015-0091-9

\section{Dr Juliana Bertoldi Franco}

(Corresponding address)

Av. Dr. Enéas de Carvalho Aguiar - 255 - 6 andar - sala 02.

Zip code: 05402-000. São Paulo / SP - Brazil.

Date submitted: 2020 May 29

E-mail: juliana.franco@hc.fm.usp.br 